\title{
Exploring the Conduct of Ethiopian Banks: The Structure- Conduct-Performance Approach
}

\author{
Tesfaye Boru Lelissa (PHD), Vice President-Operations, Debub Global Bank S.C.
}

\begin{abstract}
The study uses the views from both bank mangers and regulatory staff to investigate the behavior of banks operating in a concentrated market. As identified in the literature, such variables as bank conduct, has been a neglected topic in the traditional SCP hypothesis. This is due to the claim that bank conduct is a derivative of the industry structure on the one hand and the difficult to quantitatively test the behavior of banks in the system as the proxy variables are not quantitative by nature or else data is not available as they are not represented in the financial records of banks. The study however finds that bank conduct is not necessarily a derivate of the industry structure. Such findings from the qualitative approach witnessed a different behavior of banks than the one suggested in the SCP hypotheses. For instance, given high market concentration, banks in Ethiopia are behaving differently in price competition which remains a less essential parameter to change performances. Service difference has been an important reaction taken by the banks. Banks have been promoting themselves through a mix of approaches and attempted to increase their market share via increasing branch networks. In addition, besides market structure, regulation has been the most important variable affecting banks performance via encouraging homogenous service offerings, similar bank growth strategies and controlling their asset quality positions. Unlike what is claimed in the SCP hypothesis, the qualitative study shows that organic growth, not merger and acquisition, is considered as a dominant strategy that ensure growth in the banking system. Bank risk taking behavior also appears in contrast to the hypotheses as banks behavior towards risk is guided by the development status in the financial market as well as the competition level in alternative markets like foreign banking. The quiet life test result is also unlike the one suggested by the SCP hypotheses as banks are found to be conscious in their expense management decision. The qualitative study also explored additional variables determining bank conduct such as employee retention, top management reputation and quality of relationship with shareholders.
\end{abstract}

DOI: $10.7176 / \mathrm{EJBM} / 11-1-09$

\section{Introduction}

The empirical studies employing the SCP model, which are highly dominated by quantitative approach often fail to allow for banks' market conduct explicitly (Bikker and Haaf, 2002(a)). Instead, they treat it as being determined by structure. However, later critics have pointed out that the conduct variables are being considered among few variables which the SCP failed to consider. The qualitative analysis in this study is justified not only from the importance of including such variable in the evaluation but is also from its helpful contributions that include: first, providing useful comparison on banks' perception of their conduct in the market against the conduct deduced from the quantitative result as suggested by the SCP model. Second, bank conduct studies are also helpful in testing some of the managerial behaviors in concentrated banking industry like Ethiopia. For instance, Hicks (1935) quiet life hypothesis asserts that in a concentrated market firms do not minimize costs, because of insufficient managerial effort, lack of profit-maximizing behavior, wasteful expenditures to obtain and maintain monopoly power, and/or survival of inefficient managers (Berger \& Hannan, 1998). Therefore, firms and managers choose 'a quiet life' which result in a negative correlation between market power and managerial efficiency. Even if such behavior can be statistically inferred from the SCP model, the qualitative approach provides an in depth look on some of the behaviors of managers in concentrated (or otherwise) banking market. Third and most importantly, whenever there appears an attempt to include measures of conduct on the quantitative model, only few variables (e.g. advertising expense or selling expense etc.) which can provide a partial look on bank conduct are utilized. This is mainly related to the qualitative nature of some of the variables that may explain bank conduct and is due to lack of public information even in some of the quantifiable conduct parameters. Therefore, the researcher argues that since lack of information on variables related to conduct to a certain extent limits the generalization of the quantitative studies, a qualitative approach to explore the behavior of banks need be used.

This study intends to pursue the qualitative approach through interviewing both bank managers and regulatory staff. Bank managers are essential participants who directly involve in determining the conduct of their banks in their decision making. In addition, Bank regulators are the one who enact directives to guide the conduct of banks and determine the structure of the industry. Therefore, by collecting interview data from the two groups of participants, the qualitative study is likely to provide a better comprehensive picture on behavior of banks in concentrated market like the Ethiopian Banking Industry. 


\section{Literature Review \\ Conceptual}

In the opinion of Bain (1968), market conduct refers to the pattern of behavior followed by firms in adopting or adjusting to the markets in which they sell or buy. It is the way in which buyers and sellers behave both amongst themselves and amongst each other (Wang,2010). This happened because firms choose their own strategic behavior, investment in research, in development, advertising levels, collusions, etc. According to Moore (1973), market conduct comprises several methods practiced by traders to attract the customers to the business. It includes several price competition methods and non-price inducements. Purcell (1973) defined market conduct to refer to the actions and behavior of firms within the given structure. Pricing policies, selling cost, non-price competition are all some of the activities of market conduct. Therefore, market conduct resembles the behavioral pattern of firms in an industry. It comprises of various decision making techniques in determining price, output, sales promotion policies and other tactics to achieve their economic goals (Grigorova et al., 2008). Thus, given the structure of the market, market conduct determines firm performance. Conduct in the SCP paradigm is assumed to be directly influenced by the market structure (Bain, 1956).

As conduct involves the behavior (actions) of the firms in a market, the behavior of the firm is, therefore, determined by the structural characteristics of the industry (Mohamed, 2013). Scherer and Ross (1990) suggest that conduct in the SCP paradigm is related to the firms' product strategies, innovation and advertising. It focuses on how firms set prices, whether independently or in collusion with other firms in the market and on how firms decide on their advertising and research budgets and how much expenditure is devoted to these activities (Furguson ,1994). Conduct also takes into consideration the pricing strategies and product strategies of the firms within an industry, research and development, mergers, legal strategies, etc. and a product strategy where each firm is constantly attempting to develop new brands (Grigorova, 2008). These aspects of conduct are influenced by the structure of the market since the firm's activities are based on the environment it is in to be successful (Mohamed, 2013). Lipczynski, Wilson and Goddard (2013) provide some list of elements of business conduct that are influenced by the structure of the market that include: business objectives, pricing policies, product design, branding, advertising and marketing, research and development as well as collusion and merger. They also provide further explanation on the elements of conduct that include the following:

- The objective that firms pursue often is derived from structural characteristics of the industry, in particular the firm size distribution.

- The extent of a firm's discretion to determine its own price depends to a large extent on the industry's structural characteristics.

- Natural or inherent characteristics of the firm's basic product are likely to influence the scope for nonprice competition centered on product design, branding, advertising and marketing.

- Together with advertising and marketing, investment in research and development provides an outlet for non-price competition between rival firms. The extent and effectiveness of research and development investment, and the pace of diffusion are critical determinants of the pace of technological progress

- Collusion is another option open to firms wishing to avoid direct forms of price or non-price competition. Therefore, collective decisions concerning prices, output levels, advertising or research and development budgets will be reached. Collusion may be either explicit (through an arrangement such as a cartel), or implicit or tacit (through a less formal agreement or understanding).

- Horizontal mergers (between firms producing the same or similar products) have direct implications for seller concentration in the industry concerned. Vertical mergers (between firms at successive stages of a production process) affect the degree of vertical integration. Conglomerate mergers (between firms producing different products) affect the degree of diversification. Therefore, each type of merger decision provides an example of a conduct variable that has a feedback affect on market or industry structure.

On the other hand, there is a strong view that firm's conduct is able to influence the market structure. For instance, firms' conduct is able to change market structure through merger process. Different mergers, horizontal, vertical, or conglomerate, are of different influence on the structure of market. This is because mergers between firms could increase market power, by increasing the market share or the entry barriers in an industry (Shepherd and Wilcox, 1979). Shepherd and Wilcox (1979) argue that when a horizontal merger takes place, market concentration increases, competition reduces and the merging firms increase their market power over prices. Concluding from this, one could say that together with structure, conduct defines performance. Hence, firm's conduct is also capable of changing the market structure.

\section{The SCP Framework}

The SCP framework posits a stable relationship and a line of causality that runs from structure through conduct to performance (Church and Ware, 2000). Consequently, the original SCP paradigm assumes a one-way 
relationship between structure, conduct and performance. This is the assumption that market structure determines market conduct and thereby affecting market performance (Roth, 2005). The paradigm further assumes that firms attempt to maximize profits, that firms have perfect information and that tastes are constant, lead to the conclusion that perfect competition is the ideal market structure (Roth, 2004). The market structure of perfect competition requires five necessary assumptions that include the following: firms sell a homogeneous product; there are a large number of small firms; firms are price takers; there are no barriers to entry and exit in the long run and firms and consumers have perfect information (Beaulier and Mounts, 2008). Obviously, these characteristics are unrealistic for most industries including banking. The other assumption of the SCP is that the firm conduct is determined by the structure of the industry, hence; there will be a main linkages running from structure through conduct to performance (Bain, 1956). However, later critics have pointed that various feedback effects are also possible, i.e. from performance back to conduct; from conduct to structure and from performance to structure (Phillips, 1976; Clarke,1985).

\section{Empirical}

One of the shortcomings of the empirical studies employing the SCP model is that they fail to allow for banks' market conduct explicitly (Bikker and Haaf, (2002a)). Instead, they consider it as being determined by structure. This is with the assumption that the behavior of firms in the market is determined by the structural characteristics of the industry (Mohamed et. al., 2013). Scherer and Ross (1990) suggest that conduct in the SCP-paradigm is related with the firms' product strategies, innovation and advertising. It focuses on how firms set prices, whether independently or in collusion with other firms in the market and on how firms decide on their advertising and research budgets, and how much expenditure is devoted to these activities. Conduct also takes into consideration research and development, mergers, legal strategies, etc. and a product strategy where each firm is constantly attempting to develop new brands (Grigorova et al., 2008). A more comprehensive framework for assessing bank conduct is provided by (Neuberger, 1997). In addition to above stated factors, he has included the following factors to reflect bank conduct: branch network and quality competition, advertising, collusion, mergers, etc (Neuberger, 1997). There is also an attempt to look at the conduct of banks through indirect assessment on how customers perceive banks. However, the variables are similar with the aforesaid identified conduct factors. For instance, Zineldin (2011) has used service quality, credit availability and price competition, delivery system, promotion, etc as parameters to determine bank selection. On similar study, Saleh (2013) has used reliability, convenience, accessibility etc as a surrogate measure of bank conduct from the point view of the customer.

In terms of quantitative data representation in the SCP model, literature has used a single proxy measure of conduct i.e. the advertising expense. That means, the strategic behavior of banks is examined in terms of their selling efforts (Sahoo, 2012). The selling efforts refer to expenses by the bank towards advertising, promotion of services, and developing service networks. This is with the presumption that advertising battles may well expand or enhance the level of product differentiation in the industry and acts as entry barriers creating market concentration. Even a consensus on such interpretation is not reflected as advertising can also facilitate entry of new banks by helping them in making their product/services known to the consumers quickly so that the concentration increasing effect can be dissipated or even reversed. In addition, advertising expense disregards non-quantifiable parameters representing banking conduct like price discrimination, collusion, mergers, information gathering, innovations, etc.

Due to the above factors, the researcher argues that the attempt to assess conduct through surrogate measures like advertising expense will not reflect the situation in Ethiopian Banks. In addition, banks usually do not publicize the expense for promotion and advertising expense constitutes a very negligible part of banks' expense. For instance, the interest expense and general as well as administrative of banks constitute more than $80 \%$ of the total expense in Ethiopia (NBE report, 2016). Hence, as outlined in the framework, in-depth assessment on bank conduct might not be straightforward as testing the concentration-performance relationship. Therefore, this framework has set:

- to test the observed managerial behavior in highly concentrated market like Ethiopia by use of the quiet-life hypothesis. In such regard the hypothesis on the existence of a quiet life scenario is tested via relating concentration with efficiency measures.

- $\quad$ in addition to applying identified variables in the literature (like price competition, branch network, competition, promotion, innovation, expense preference and risk mergers etc.), to qualitatively assess their further enhancement or decline resulting from the test of the SCP and quiet life hypothesis.

By doing so, the framework provides a fertile ground to test the research sub-questions related to investigating the conduct of Ethiopian banks with the given structure and performance determinant factors. 


\section{Conceptual Framework}

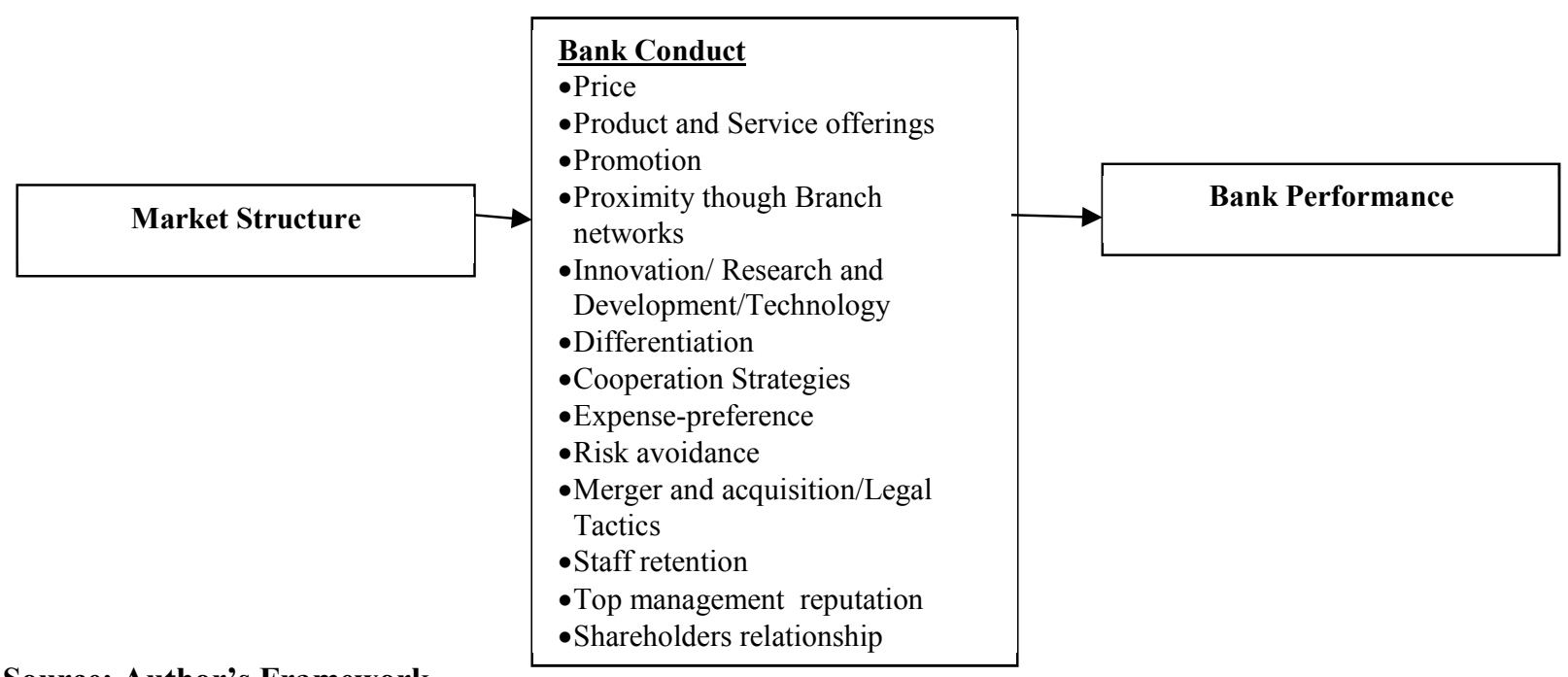

\section{Source: Author's Framework}

\section{Methodology}

The study gives an overview of the qualitative analysis of 18 interviews that were conducted with participants of bank managers and regulatory staff. The interview is conducted with managers of 7 commercial banks and 4 Central Bank staff. Of the commercial banks, one is from a state owned bank and the remaining six are from private owned banks. The representation for state owned commercial banks is $100 \%$ as the recent merger decision from the government has amalgamated the two stated owned banks. As discussed in the methodology section, the private banks were taken following a purposive sampling approach and in a way to represent both middle and recent entrant banks. The duration of interviews ranged from 45 minutes to an hour, and interviews were conducted at a place convenient for the participant (mostly at their offices and few are conducted by phone). The main topic of the interview was the participant's experience related to the banking industry. From the literature review and established conceptual framework, the study, therefore, has identified the following aspects of bank conduct as preliminary start-up of the interview session: price, product/service offerings, research and development, technology introduction, differentiation, promotion, quiet life and expense preference, cooperation strategies. A qualitative content analysis consisting of counting and comparing quotations, keywords, or paragraphs followed by the interpretation of the underlying context is used to drive a meaningful explanation on the subjects discussed. A direct quotation of some of the interviewees' opinion is presented between the analyses.

\section{Qualitative Data Collection and Analysis}

Data for qualitative studies can be collected from different sources of evidence, including documents, archival records, interviews and so forth (Yin, 2003). In this study, an in-depth interview is conducted to collect qualitative data. In addition, this is complemented by a review of documents such as directives, legal codes, the country growth plan and other pertinent materials guiding the banks' conduct.

\section{Interview}

As common with quantitative analyses, there are various forms of interview design that can be developed to obtain thick, rich data utilizing a qualitative investigational perspective (Creswell, 2003). These include the three fundamental types of research interviews: structured, semi-structured and unstructured. In this study, interview questions are designed to be semi-structured as they allow the study to be benefited from both structural and unstructured approach. The structured nature provides key questions that help to define the areas to be explored, hence, ensuring cross-case comparability (Bryman, 2004). On the other front, the unstructured approach allows the researcher and/ or the interviewee to diverge constructively in order to pursue an idea in more detail (Gill et. al., 2010). With such background, two sets of interviewees, namely, bank senior managers and bank regulators are selected in order to provide a comprehensive picture on the objective of the study. The variables adopted in the conceptual framework are used to formulate the interview.

\section{Interview Participant Selection}

Interviewing individuals from a variety of perspectives has the potential to enhance the credibility of findings (Rubin, J and Rubin, S, 2005). Therefore, two sets of interviewees, namely, bank managers and bank regulators are selected in order to provide a comprehensive picture of bank conduct. This is mainly because bank senior 
managers are believed to be those who have broad knowledge about their bank's strategies, policies, and business practices. They are also the ones being involved in different aspects of decision making and strategic choices on their bank. Besides, they also are better aware about the industry situation and the regulatory environment in the Banking context. Thus, it is expected that they have better ability to understand the research problem than those non-managerial staff. Similarly, bank regulators who are guiding and regulating the banking sector are chosen as they are specialists with much broader knowledge and understanding about bank regulation and policy setting. Therefore, the study employs purposive sampling techniques to select interview participants.

\section{Sample Size}

The sample considered in the study consists of 18 interviews that were conducted with participants of bank managers and regulatory staff. The interview is conducted with managers of 7 commercial banks and 4 Central Bank staff. Of the commercial banks, one is from a state owned bank and the remaining six are from private owned banks. The representation for state owned commercial banks is $100 \%$ as the recent merger decision from the government (while the study is in progress) has amalgamated the two stated owned banks.

In essence, qualitative interviews are conducted to explain and explore phenomena in depth to discover new constructs, themes and relationship. Considering the similarity of bank behavior in Ethiopia, the sample of 18 bank experts and regulators remained adequate enough to reach saturation levels. Alvesson and Skoldberg (2010) define saturation during interviews as the point when no new data is revealed by further collection of data since all the questions asked have been exhausted by the initial qualitative interviews. The sample selection considers the historical formation time of banks and their ownership structure. The private banks are taken following a purposive sampling approach and in a way to represent both middle and recent entrant banks following the following strata:

- Private banks that operated in the industry for more than a decade and whose asset size is above Birr 5 million: banks under this category are those that emerged after the financial reform measure and mainly of the measure that allowed the participation of the private ownership in the banking sector)

- Small size banks with asset size less than Birr 5 million and stayed in the industry form less than a decade: These banks are small in size and are relatively short-lived in the sector.

Hence, based on the above classification, bank experts working for government owned bank (Commercial Bank of Ethiopia(CBE) which amalgamated with the Construction and Business Bank( CBB)), middle size private banks and small size private banks are considered for the research. Three middle size and three small size bank managers are interviewed. Input from managers having a diversified skill set such as those working as risk, planning and research and bank operation managers is obtained. Comparably the interview with bank regulator staff is with those who are in a team leader position.

\section{Qualitative Data Analysis}

The data collected from interview is analyzed through thematic data analysis through examining and recording patterns (or themes) within data. It is performed through drawing a meaningful explanation on the pertinent subject from the responses of the banking experts. Some of the responses are quoted and presented in the analysis part. In addition, as set in the conceptual framework, variables that convey conduct such as price competition, advertising and marketing practices, branch network and quality competition, information gathering, expenses preference behavior, risk avoidance etc are used in the analysis structuring process.

\section{Reliability and Validity in Qualitative Research}

Denzin \& Lincoln (2005), state that the issues of validity and reliability are important in qualitative research. However, they are treated in a different manner as there are no intentions to establish a quantitative measure of validity and reliability (as in the case of quantitative research). Stenbacka, (2001) viewed reliability as 'purpose of explaining' in quantitative approach and 'generating understanding' in qualitative approach to research. Owing to the desire to differentiate itself from quantitative research, qualitative researchers have espoused the use of 'interpretivist alternatives' terms (Seale, 1999). For instance, Lincoln \& Guba (1985) suggested that the most suitable terms in qualitative paradigms are credibility, neutrality or confirmability, consistency or dependability and applicability or transferability. This study uses the suggested names by Linclon and Guba together with preferred names for quantitative analysis so as to solve the confusion in this regard.

\section{A. Reliability/Dependability}

Saumure \& Given (2008) recommended that dependability can be addressed by providing a rich description of the research procedures and instruments used so that other researchers may be able to collect data in similar ways. In addition, researchers may address dependability by conducting a new study on participants with similar demographic variables, asking similar questions and coding data in a similar fashion to the original study (Firmin, 2008). Therefore, it can be inferred from the above that clearly stating the demographic of the variables and 
research questions used to collect data and the coding techniques should be explained clearly.

In this study, therefore, to ensure reliability:

- the interview procedure (the timing, content, etc.) and the data analysis process is discussed clearly;

- the profile of interviewees is explained in detail;

- the interview questions used to collect the data from interviewees are clearly prepared ;

- detailed note in which each interview session is held is included but attempt to record the interviews is not allowed as participants' were not willing to do so;

- During the data collection process, efforts were made to reduce errors and bias. In this regard, before closing the interview sessions, the researcher tried to check the accuracy of the data by discussing the points taken on the note with the participants and getting their feedbacks.

\section{B. Validity}

i. External Validity (Transferability)- emphasizes the generalization of the research findings. It is easy to understand generalization in a quantitative study. However, the claim about generalization in qualitative research is more problematic due to the small samples often used in qualitative studies (Johnson et. al., 2008). The major intent of the qualitative part in this study is to explain behavior of banks in Ethiopia as compared to the expected behavior from a concentrated market as suggested by the SCP model. Therefore, as Bryman (2004, p. 285) argues, 'the findings of qualitative research are to generalize to theory rather than to population.'

The external validity of this study can be enhanced through the following ways:

Purposive sampling allows the researcher to select the cases that represent the feature of the researcher interested in (Silverman, 2001). The interview participants are mainly those that can contribute well to the study; therefore, the selection is purpose rather than random. This ensures to collect the opinion of bank experts and regulators who are expected to be knowledgeable on the research theme. The study investigates data from multiple cases gathered from different banks, therefore, reliance on few cases to explain a scenario from the quantitative result is avoided. The case selection is done to incorporate different bank groups segregated via ownership and year of stay in the industry. Bryman (2004) suggests that studying more than one case is a helpful solution to improve generalization in qualitative research. The study also has diverse opinion on the central research questions from the perspectives of both bankers and the regulators. The use of two sets of interviewees, therefore, is helpful to enhance validity. Parry (1998) argues that gathering multiple perspectives on the same incident can help to moderate the negative impact of single sources on research validity.

ii. Internal Validity (Credibility) - Internal validity in qualitative research refers to the extent to which the observations and measurement represent the social reality (LeCompte and Goetz, 1982). It is concerned with the research methodology and data sources used to establish a high degree of harmony between the raw data and the researcher's interpretations and conclusions. McMillan \& Schumacher (2006) suggest list of strategies to increase validity in qualitative research paradigm of which those associated with creditability includes: accurately and richly describing data, citing negative cases, using multiple researchers to review and critique the analysis and findings and conducting member checks.

In this study, therefore:

- the researcher examines carefully the inferences drawn from the qualitative data by adopting the thematic analysis (classifying the qualitative inputs into various themes) to guide the discussion of results.

- unexpected concepts and controversial issues from one interview session are discussed with other interview participants. The research follow-up for surprises rather than dismissing them, and took into consideration rival explanations and possibilities and tests if all participants have the same views about the theme/s that occur.

iii. Construct validity (Conformability) - it refers to establishing correct operational measures for the concepts in both quantitative and qualitative studies (Yin, 2003). In other words, the researcher should ask the question: 'am I truly measuring /recording what I intend to measure /record rather than something else?' (Tashakkori and Teddlie, 1998). Researchers may address conformability through the use of multiple coders, transparency, audit trails, and member checks. In the qualitative study, the researcher's subjectivity and bias existing in the data analysis process pose a significant threat to the construct validity. In this study, it might not be feasible to use multiple coders technique to reduce researcher bias. However, the researcher rechecked the inferences drawn from the interviewees' opinion and audit trial on the collected data including connecting the result to existing literatures.

\section{Analysis Results}

Price

On the price aspect, one of the important findings is that market abuses resulting from collusive behavior appear 
insignificant to affect the prices paid to resources as well as the interest earned from loans. This remains to be one of the surprising results in a market structure like the Ethiopian banking system (tight oligopoly ${ }^{1}$ ) where few large banks were predominantly taking the lead in major market areas. The views from both groups of interviews have been similar and show that price has been set independently by the decision from the banks. Nevertheless, there were instances from the private banks to agree not to compete through prices or engage in price wars which were agreed to cause negative repercussions on the competitive environment. As shown in the interview, however, such attempts have also been constrained by several factors not to ensure collusion.

'The government bank which stood a price setter more specifically related to lending business, has a tendency to set the price at reasonably lower level than our bank and other private banks following its motive to access to finance to the wider community. We cannot call for a much higher price than the price set by the state owned bank because if we do for sure our customers will switch to the state bank demanding for lower prices.'(Interview BM7).

'We (private banks) through our banker association have agreed not to compete on price basis because at the end the cost of the decisions to engage in price war affects us more. For instance, any increase in our interest rate for deposit even if it allows for more deposit mobilization will narrow the spread from intermediation. We always might not have a privilege to keep a constant spread through increasing the lending rate.' (Interview $B 12$ ).

'We (CBE) are a big bank with notable size difference. With whom do you think we can collide if we prefer any sort of collusion?'(Interview BM14).

'We (NBE) set the price for saving and fixed time deposit, because we need to lessen the propensity for banks to abuse the market through offering a lower rate to depositors. In addition, such variable is being used as a monetary policy to determine the amount of deposits kept in the banking system. The revision in rates has a tendency towards encouraging saving and investment in the economy.' (Interview RS1).

From the inputs of bank managers and regulatory staff, the study finds that:

- government owned banks which are on top of the efficiency front are enjoying the privilege of large market of cost saving deposit from public enterprises. Therefore, the cost of fund of the bank remained lower than the industry leading to less motivation to improve performances through price related measures.

- one of the guiding business motives of the state owned bank is related to undertaking social responsibility through ensuring accessibility, raising bank awareness and use, financing priority sectors as set in government policies. This remains distinct from the motive of the private banking system which predominantly relies on maximizing shareholders' wealth. Therefore, such variation in business objectives and ownership structure has led different perspectives across the banking system in relation to collusion on prices setting.

- the other scenario which obtained attention is that the substantial difference in the size of state and private banks has limited the possibility of market collusion. This is because the big bank will not have a motive to cooperate with small banks to ensure market collusion. The big is always big no matter how it collides with other or not.

- the observed price related cooperation, as a reflection of market collusion, belongs to the private banks which have a reduced share of the market. The private banks have signed a memorandum of understanding not to compete on price bases. The effect of such move to cause market collusion, however, is constrained by several factors including:

- The private banking system remained a price taker as the big state owned bank takes in the price setting responsibility related to the intermediation business. The price for credit of state owned banks appears less than the private counterparts. This constrains the private banks not to deviate much from the price set by the state banks. Otherwise, a notable deviation in prices enforces the private sector customer to make shift to state owned banks demanding for lower government services.

- The minimum price paid for saving and fixed time deposit is set by regulation and hence provides little room for the private banks to envisage better earning through reducing their costs of deposits.

- Homogeneity of services offered by both private and state owned banks has also eased the switching cost of customers and rarely enabled a platform to institute a variable price based on service differentiation.

\footnotetext{
${ }^{1}$ Salvalore (1998) identifies four different types of market organizations i.e. Perfect competition at one extreme, (b) Monopoly at the opposite extreme, (c) Monopolistic competition and (d) Oligopoly in between. In addition, Shepherd included the concept of the dominant firm as a firm having $50-100 \%$ of the market and no close rival. He further classified oligopoly in two to as tight oligopoly (The leading four firms combined $60-100 \%$ of the market) and loose oligopoly (The leading four firms have $40 \%$ or less of the market).
} 
- On the other front, the less risk taking behavior of banks which is a result of stable market condition and regulatory restrictions has impacted any attempt to pursue on price collusions.

- Market protection from foreign banks as well as local banks such public banks have also affected the price setting mechanism in the market. Price therefore is not mainly a result of the supply and demand theory but remained fixed in most of the period unless there is a move for the regulatory to alter interest rates.

Overall, even if there has been an effort from the private banks' system to engage in price collusions, its effect has not been significant, but has helped banks to enjoy stable earnings from intermediation business with a liberty to alter their lending prices in a way to keep their spread constant. Therefore, price remains not a worry to the banks and is not considered as an essential parameter to change performances. In addition, price related measures are discouraged through regulation, different motives of state owned and private banks, substantial size difference, risk taking behavior and market protections. This remains to be one of the critical theoretical contributions of this study. In market situations, dominated by big size bank but with notable size difference across firms, where price regulation guides price setting mechanisms, an attempt on price collusion remains ineffective. In such scenario, banks desire not to compete on price basis and prefer the option that keeps their earning level constant.

\section{Product and Service Offerings}

The banking sector, characterized by multi-product/service offering, is distinguished by homogenous type bank product and service offerings. This is because bank products have the characteristics of being easy to copy and lack adequate patent protection. As a result, competitive advantage that a bank gains from its products/service offerings may not last long (Watkins, 2000). Similarly, bank managers and regulatory staff mostly have expressed a related view with the above arguments. For example,

'As you are well aware banks offer similar range of intermediation and payment services. Pursuing product specialization is not an easy task considering the easy adoptability and lack of protection.'(Interview RS3).

'Banking by nature is a universal service. The banking products offered are homogenous not only in Ethiopia but also across the world. What we attempt to do is to position the products well in the market. However, our product offering are similar to other banks.' (Interview BM13).

'... If we introduce a new product today, then after a few days, even tomorrow, all other banks would have the same product.'(Interview BM2).

Nevertheless, there is a different view with regard to services among bank managers:

'We treat services to be different from products. Banking products can be easily copied but the intangible services are not. We try to be different in service delivery and that is the major reason why customers choose us.' (Interview BM9).

'Services to certain extent can also be copied. However quality of services delivered in consistent manner, customer treatment and relationship are the foundation to our competitive advantage.' (Interview BM6).

A similar direction has been pointed by the regulatory staff:

'We don't want banks to involve in price wars. What we encourage a war between banks (if any), is the war through service differences. We need to ensure that banks are well positioned to provide convenient services to their customers. Compliant from service failure such as maltreatment of clients, customer discrimination could also result in penalty. This is unlike a failure by a bank not to introduce products. Except failure on core product offerings such as account opening, forex services, credit etc the choice of product introduction is an option left to the banks management.' (Interview RS3).

As explored from the interview result, bank product offering in the banking system remains homogenous as a result of lack of patents for bank products and the tendency to get easily copied. Although managers and regulatory staff in general recognized that bank product offerings are homogenous, they consider them as a key source of their competitive advantage. For example:

'.... this (similarity of bank products) did not mean that bank products are not important. They remain to be a foundation upon banks could make an impact on performances. A bank having full-fledged services at its branch could attract more customers than a bank with limited product offering at its branch.' (Interview BM2).

'You know, the bank products offerings carry the brand of a bank. If you have a good brand with full package product offerings then you can produce significant incremental revenue or profitability. (Interview BM11).

The above statement shows that in addition to services, product offerings are also important from managerial perspective. Overall, with the existing banking structure,

- the banking system in Ethiopia is offering homogenous products with an added value on products 
through:

- Adding a range of services provided to products

- attaching brand value to the homogenous products

- concerned to provide full fledged banking product menus to the customers

- $\quad$ service difference has been an important reaction taken by the banks to win market share and build their competitive advantage. This however is driven by both:

$\circ$ Internal and intentional motive of the management to attract customers

$\circ$ A regulatory direction that encourage banks to compete and differentiate themselves from the move of the market.

\section{Promotion}

Promotion is one of the essential activities of businesses to properly position themselves in the market. The benefit arising from the promotion not only affects the financial performances through spearheading business activities but also creates an added value in the form of goodwill. Nevertheless, such understanding might not be equally shared and utilized by all banks in the system. Moreover, specifically, banks operating in a concentrated market will have a lower tendency to promote their services as the customer is left with a meager option to select among service offerings of banks. This is because the concentrated structure will provide little choice to customers as there are few banks operating in the system. In addition, banks in such structure usually have the upper hand in the market following the large demand for banking services, more specifically of those related to credit and forex resource offerings. Therefore, large demand restrains banks to allocate huge investment on promotion. In order to explore the banks' strategy towards ensuring a growing market share through promoting their product and service offering, the following question has been framed: 'is promotion important to banking business and what is the significant of promotion?' There is a common view regarding the importance of promotion across bank managers and regulatory staff:

'Yes, I believe that banking services and products should be promoted. This is not only from the perspective of ensuring better performance through increasing the number of customers but also to ensure a wider banking awareness among the society.' (Interview BM7).

'Banking by nature is a service engagement whose delivery and approach need to be promoted to customers through various approaches. If you are not promoting products how the customer knows that you are different?' (Interview RS4).

'A critical part of banks asset is the goodwill associated to its brand. You cannot think of a brand and positioning without having a successful promotion program. In addition, bank promotion enables your presence in the market, branch location and product offerings. '(Interview BM5).

Overall, the interview findings show that despite the homogeneity in product service offerings, there is a consistent understanding that banks need to promote their product offerings to their customers. The benefit associated with promotion to banking business as pointed out in the interview includes:

- promotion positively contributes to improved performances through increasing the size of banking business. This consists of both ensuring a growing business from new clients as well as existing customers of banks. Hence, bank usage rate increases with the effort of promotion.

- the interview result also pointed a benefit beyond financial success of using promotion. Promotion can be effectively used as a means to create banking awareness among the wider society. This in the future will be a potential platform to increase the banking customer bases.

- $\quad$ promotion has also been cited to have important implication on bank differentiation. Banks can tell to their customers on their specific specialties or competitive advantage through promoting their different offering to the customers.

- promotion is also found as a critical component of the banks engagement to build image in the market. This is translated in the form of a strong brand that offers the benefit of well positioning in the market.

- furthermore, promotion provides information to customers on branch location, prices, and product and service offerings.

With the backdrop of such benefits and purpose of promotion, bank managers are asked about the method of promotion applied in their bank: what promotion approaches are used by your bank? The study result shows a slight variation across banks on their promotion approaches. However some banks have been utilizing innovative promotion approaches like customer visits, social media etc. For example:

'We have been using the common media of promotion such as ensuring a consistent presence on local Tv channels, radio programs, on print medias. However, we usually look for to increase the rate of customer referral through personal selling.' (Interview BM4).

'We have found the presence on medias like Tv and radio a bit expensive which limits our intent to appear in such type of commercials on frequent basis. Therefore, we usually prefer the personal selling approach. We also invite potential clients through arranging a customer tour program in our bank 
premises. We are also observing another cost effective media, the social media like facebook, twitter and business sites linked-in to promote our bank' (Interview BM10).

'We are successful to win promotion in the print media like publications on newspapers at a dedicated page and magazines (cover and back of the page). In addition, we use frequent TV and radio presence along with a lottery campaign encouraging savers and forex transfers.' (Interview BM6).

The above explanation points that banks have been promoting themselves through a mix of approaches and consisting of personal selling, customer visit, TV and radio advert, publications (newspapers and magazines), social media, lottery offerings etc. Nevertheless, aggressive promotion attempt viaTV and radio targeting the mass market is affected by the high investment requirements. This enforced banks to divert their promotion approach to other cost effective media. In addition, some banks appear innovative in their approach through scheduling customer tour events, arranging lottery programs targeted to encourage saving and forex earnings, as well as utilizing customer referral which is based on service satisfaction as an effective form of promotion. Overall, given the market structure, banks (both state and private) have been considering promotion as a means to ensure financial success, encourage savings, forex transfer as a means to create banking awareness.

\section{Differentiation}

The degree of differentiation is another important factor that determines bank conduct. This is because absence of differentiation (homogeneity) would impact conduct and performance so that there is one price for all sellers and the market shares are determined randomly (Bain, 1968). Therefore, differentiation is important in structure since it could strengthen the firm's market position and profit and acts as an entry barrier (Church/Ware, 2000). This is due to the fact that in case of strong brand loyalty, the new entrant should convince consumers to buy its product instead, by offering better terms e.g. quality or price, or greater advertising (Church/Ware, 2000). Indeed, the differentiation approaches are diverse to include services, products, markets, marketing approaches etc. With such background, the study has proposed to investigate the degree of differentiation in the banking system by forwarding a question to bank managers that reads, 'what is the differentiation strategy of your bank?'

The responses obtained are much directed towards lack of a specific differentiation approach in the banking system with few exceptions related to market differentiation strategy followed by few banks. For example:

'Even if our bank (name omitted) is privately owned, we are a bank of the public. Therefore, our product offerings target the mass population. We offer common banking products positioned through a mass marketing promotion approach.'(Interview BM3).

'We consider both retail and corporate markets addressing their demands through variety of service offerings. We provide focus to the retail business with the motive to mobilize resources from diversified sources. However, we consider our service offering as a differentiator but offer similar products and pricing mechanisms.'(Interview BM5).

'...(name omitted) bank is privately owned public banks but offers a wide range of products and services to retail and corporate banks. In addition, it also offers products to specific markets (like interest free banking). Even if our products are the same we are engaged in aggressive promotion and service differentiation.'(Interview BM10).

A manager at a bank however explained that:

'We (name omitted) offer a differentiated banking products to' a niche market' structure targeting the corporate clients. The retail banking approach requires a large branch and staff which have a bearing on our cost of doing the business. Therefore, we have introduced a single branch banking model supported by multichannel banking approaches and technology frameworks. Currently however we are heading to the retail business through increasing branch outlets and extending our market reach to the retail business. Such change in a strategy is mainly a result of push from the regulator.' (Interview BM2).

From the interview experience, it is found that:

- market differentiation is not a widely used approach in the banking system. Majority of the banks are serving both the corporate and retail clients with minor modifications on their product offerings. Even some banks target the retail business, which is a mass market, with the basic aim of collecting resources from diversified sources. This ensures banks to manage the risk arising from deposit concentration through operating on a diversified deposit base.

- $\quad$ service differentiation, however, appears to be the way followed to differentiate bank offerings in the market. Nevertheless, the practicality of such approach is paradoxical on the ground that and as stated in the interview most banks are not in a position to differentiate their markets. Therefore, ensuring a differentiated service in a mass market remains to be a practical challenge to witness the existence of service difference. This is because the differentiation might not be observable and felt by customers If banks are serving different client groups at same outlets with similar products, 
- most banks are also following comparable marketing approach targeting the mass population. The promotion package also seems ineffective to differentiate the market and customer segments. This among other justifies the rarely observed differentiation with regard to the promotion approach followed by banks.

- $\quad$ an important exception to the aforesaid scenarios is that there was an attempt by a bank to serve a niche market through targeting corporate clients. This has been done in a way to address the need of the market segments. However, regulation tends to reverse the move of such bank towards public bank offering as done by other banks in the system. Such regulatory enforcement, therefore, remained an important variable in the system directing banks towards homogenous service offering targeting the mass market.

Overall, the banking system in Ethiopia mostly follows a mass market approach addressing the need of both retail and corporate clients with undifferentiated product and marketing approaches. In addition, regulatory measures also discourages differentiation related to market demanding for a homogeneous market reach and ensuring a growth approach through opening large branch networks mainly serving of the retail businesses. This remains to be one of theoretical contribution of the study that banks operating under tight regulatory regimes; regulation intends not only to ensure the safety and soundness of banks but also to influence the growth strategy of banks by directing banks on the market they serve and their accessibility requirements. In addition, banks operating under tight policy framework will not have an option to choose their differentiator strategy. The only allowable differentiator, service offering, will also remain ineffective in cases where a wide market differentiation approach is not allowable to be pursued. Technically, therefore, the regulatory move among others calls for homogenous bank offering discouraging differentiation in most areas of activities.

\section{Proximity though Branch Networks}

One of the policy frameworks guiding the growth of banks through ensuring accessibility of financial services to the community is branch growth. The study aims to find out the reason behind an aggressive branch opening move from the commercial banks despite its cost implication. Therefore, the study has raised the following questions to obtain the views of bank managers and regulatory staff: What is your stand regarding bank growth through the traditional branch network? How do you explain the negative impact of branch growth?

'We consider building a wide branch network as a vital instrument in the resource mobilization effort.

Large branch network not only ensures growth but also provides the benefit of obtaining a diversified deposit source. At the backdrop of this branching has an obvious disadvantage of demanding effort to manage large resources, contributes to cost increase through lifting branch running costs in the form of staff size and rents.' (Interview BM14).

'I consider branching as one of the critical success factors for better bank performances. This is because branch offers the advantage to promote banks, creates convenience to customers ensuring proximity of services, and allows growth enabling market reach. Nevertheless, branching has a demerit of restricting differentiation, exposes bank to costs related to internal control to prevent employee mal practices.' (Interview BM10).

'A branch remains an important point of contact for customers. Through opening large branches you will get large number of marketing staff, the branch managers. Therefore, you don't need to highly involve in promoting yourself through high cost channels like TV and radios. Branching however impact performances through ensuring large stock of non profitable branches. Unless the head office effectively uses the resources from branches, the cost of opening the branch outweighs the benefits.' (Interview BM9).

'I take branching as a critical means to cope the competition in the system. Banks are competing through increasing the branch network. I would allow my bank to neglect the move of other banks and limit branch growth. I know that excessive branch network has cost implications, boosts the competition in the sector, and takes management time.' (Interview BM1).

'We consider branch growth not only as a financial success determinant but also ensure the government stance for financial inclusion through allowing access to finance. Branching decisions might not have a large negative impact on performances as long as banks are able to position their branches well and monitor their performance of their branches. This is one of the areas to pursue a responsible banking culture through offering banking services near to the premises of the under banked population.' (Interview RS2).

Participants suggest that branch network quite often offers benefit to the growth in the size of banks. Nevertheless, from suggestion put fore ward of the weakness of branching, it is inferred that branching has an obvious implication on cost and hence profitability. In line with the findings, branch opening, however, remains a critical move for most of the banks. This is explained from the perspective of:

- $\quad$ offering a reliable means to mobilize large resources from the wider community; 
- allowing diversification of the resource bases of banks;

- $\quad$ promoting banks and appear as an important channel to promote bank product and service offerings;

- creating convenience to customers through ensuring proximity of services;

- allowing bank growth by enabling a wider market reach;

- $\quad$ allowing the benefit of a decentralized marketing scheme through offering assigning branch managers as marketing staff to promote the bank;

- $\quad$ Substituting high cost promotion channels like TV and radios;

- chasing the move from the competitors; and

- Supporting the pro poor policy via allowing financial inclusion and access to finance to the poor.

Nevertheless, the benefit explained to branches has been pointed out to have recognizable drawbacks. This is well cognizant by the bank managers as well as the regulatory staff. However, regulatory staff has a perspective that branches' impact on performances could be improved through a resilient system of branch performance management. The drawbacks of a large branch network growth on performances suggested in the interview include:

- it demands the effort and time of management to manage large resources;

- branching contributes to cost increase affecting profitability. More specifically, the cost increase is associated to branch running costs expressed in the form of increase in staff size and branch premise rent costs;

- it has a demerit of restricting differentiation through ensuring a determined way offering services ;

- branching also enforces banks management to spend high cost in strengthening their internal control system so as to protect the branch being affected by employee mal practices like fraud;

- $\quad$ it impact performances through ensuring large stock of non profitable branches. Unless the head office effectively uses the resources from branches, the cost of opening the branch outweighs the benefits; and

- besides, the notable cost implications of branching, boosts the competition in the sector.

Overall, the negative relationship of branch growth on performances, therefore, is a result of the significant cost of branch opening that negatively affects profitability. Branching also impacts performance by increasing the cost of establishing a robust internal control system. Furthermore, large branch network has also some hidden costs related to consuming management time to handle bulk resources, boosting competition among banks and restricting differentiation. However, this has been implied to result not only from the financial implications of branch opening, but also from the effective use of head-office to use branch resources as well as management's capacity to lift up weak performing branches etc.

\section{Innovation/ Research and Development/Technology}

Another perspective to look at banks conduct is via exploring banks behavior towards engaging in research and development. This ensures banking as a knowledge based endeavor to be competitive in the market through non price related undertakings. The innovative activity involves not only products but also include processes, marketing, services, etc, supporting banks' attempt to develop new brands (Grigorova, 2008). The study forwarded the following questions to bank mangers: What is the commitment of your bank towards research and development? Does innovation identified as a major component of the strategy of your bank? What are the key innovation focus areas and the challenges thereof? The study result confirms that conceptually banks accept the relevance of innovation in sustaining the well being of the bank in the growing market competition. However, the challenges are pervasive. For example:

'We support innovation being a pillar to our bank growth. It determines not only growth but also ensures sustainability of the bank in the market. Customers now days are demanding for more innovative products and services. This has been spearheaded by the increase access and use of technologies. Therefore, our innovative approach targets technologically supported products delivered through mobile and internet. The main challenge associates with the low usage rate of the products, preference to branch services, high cost of investments etc.' (Interview BM11).

'I consider innovativeness to be a mandatory path to follow by our bank in the future. It offers not only bank efficiency via reducing service delivery costs but allows customer to enjoy banking services on demand. Banks need to be omnipresent to serve their customers everywhere and upon demand. This has a challenge from acceptance from regulation, lack of internal capacity to introduce innovative ideas.' (Interview BM4).

'As a reflection of the reliance on the importance on innovation, we have established an internal knowledge and innovation unit which brings world standards and innovation ideas to our bank. We consider this as critical to our survival and as a competitive advantage to win the market. Nevertheless, strict regulatory barriers, rigid KYC requirements, underdeveloped technology infrastructure, capital intensiveness of innovation and low usage rate are the reasons holding us back in the innovation 
front.'(Interview BM7).

'Technology related innovation is emerging as a preference of customers. However, still our customer prefers to use our branch network for banking services. The low level of awareness, lack of legal framework to handle cyber crime, under developed technology infrastructure following a sole owned internet supplier, easy adoption of innovative products has limited our move not to be aggressive in such front.'(Interview BM12).

Banks find that technology (like the internet and mobile based) related innovation have important implications not only on their financial performances but also on their future well-being and competition strategies. This is because the bank customers, who have more access and use of technologies, are demanding for more innovative products and services. Besides the demand from customers, innovation offers positively to bank efficiency via reducing service delivery costs and addressing the customer need for on demand banking services. To fulfill such motives, some banks have established an internal knowledge and innovation unit which work to introduce world class standards and innovative ideas. Nevertheless, the innovative move of banks has faced several challenges that include:

- low usage rate of technology related products arising from low level of customer awareness;

- customer preference to branch banking services that comforts bank customers through face to face interaction;

- high cost of technology driven products;

- regulatory need to endorse new products;

- lack of internal capacity to introduce innovative ideas;

- lack of legal framework to handle related cyber crime increasing the security of banks;

- $\quad$ under developed technology infrastructure following a sole owned internet supplier;

- rigid requirements related to $\mathrm{KYC}$ in the attempt to control money laundering; and

- Easy adoption of innovative products by competing banks limiting the first mover advantage.

Overall, innovation appears to be one of the behaviors determining bank conduct in the Ethiopian banking system. Nevertheless, its level of impact has been challenged to impact the industry performances due to several factors including costs, lack of capacity, low awareness level, easy adoption rate, lack of well developed infrastructure and regulatory barriers, etc. However, the effect of regulatory restrictions on innovativeness is not accepted by the regulatory staff. for instance, interview RS3 explained that:

'We have been directing banks to be more innovative. Even we have taken the foremost important step of enforcing banks to operating with a core banking system. in addition, we have established a framework for banks to share borrowers information online, automated the payment system and a system to network bank ATM so that they can be accessed by all banks customers.' (Interview RS3).

From the above explanation it can be inferred that the regulator has been supporting banks to introduce and use technology related products. However, the regulatory stance is mostly directed towards creating a common platform to share technology and technology resources among banks in the system. The regulator doesn't seem to accept technology difference as an important arm banks competitive advantage. Even the move in some areas like sharing ATMs also discourages banks not to invest in e-products that will not allow creating market differentiation and offering for distinct bank services. Therefore, regulatory move on the one side is supporting technology use by banks. Nonetheless, it is also limiting differentiation through technology related product offerings. The long waiting times to secure approval of new products from the regulator however is perceived by banks as a barrier limiting the innovation endeavor of banks.

\section{Legal Tactics/ Merger and acquisition}

Banks face competition from both rivals in the banking sector and in the non-bank firms such as microfinance. Through merger and acquisition (M\&A), large banks become multi-product financial service and multinational conglomerates in order to exploit scale economies (Berger et. al., 2010; Buch and Delong, 2010). Whereas small banks focus more on traditional strategy that allows them to deliver highly differentiated small business products and banking services (DeYoung et al., 2004). In Ethiopia as well, recently, the two state owned banks, the CBE and CBB have merged together with the intent of ensuring better control of state resources. This has created a wide spread sentiment in the private banking system as a coerced move towards merger and acquisition. The capital requirement at the end of the GTP II period is considered by some banks as a guiding standard leading to forced merger. Nevertheless, there appears no clear statement on what will happen to a bank that fails to meet the capital requirement. From the interview experience, however, it is explored that banks have no intention to engage in willful merger unless the regulator insists on the process. This is mainly due to the difference in the approach of market segmentation (by region, religion, political group niche etc) and the positive perception related to the untapped market for banking services in the country. For example a bank manger BM5 noted that:

'We opt for organic growth as our market base, as set by the founders of the bank, is distinct and cannot 
fit with other banks. Moreover, we are growing well with high profitability records, so what merger could do to us?' (Interview BM5).

Banks, however, seems prepared to accommodate mergers in case the regulator claims for forced merger and acquisition progression:

'During crafting of our strategy we have analyzed the effect of merger and acquisition. That will help us to get ready in case there is a push from the regulatory organ.' (Interview BM9).

The interview with the regulatory staff shows that there is no plan from the regulatory side to enforce banks to engage in merger process:

'We don't have a plan to force banks to merge. But banks can take such strategy as one way of ensuring growth. The issue of merger cannot be raised from our side as long as banks are performing well ensuring safety and sound business. '(Interview RS2).

Overall, merger and acquisition are not considered as one way of ensuring growth in the banking system. Except on few cases, banks strategy entirely relies on organic growth. This is because of the convenient scenario in the industry to ensure natural growth as well as variation in the market segmentation strategy of banks. Nevertheless, there is a potential for merger and acquisition process during the times when the regulator trusts that banks are not safe and sound to deliver banking services. Therefore, bank merger and acquisition process mostly are not driven internally by the choice of banks' management and cannot be considered as a significant factor determining the conduct of banks at least at the current time. In the future, when bank competition grows and rivalry develops, the option appears a second way out set by the regulator for banks to forcefully accept it.

\section{Risk Avoidance}

There seems a tendency towards a high risk taking initiatives among the banks in the system as reflected in a heated intermediation business that positively relates with profitability. In order to explore the issue further, the banks' choice on risky activities is a question that has been set: what is the risk taking experience of your bank? The managers' views on it shows that banks prefer to engage in the intermediation business, which is a risky activity, because there are limited areas of banking activities as well as other options like forex business alone cannot ensure growth and profitability motives because of the acute shortage of foreign currencies in the market and due to lack of a well developed market. For example:

'We know that we should take high risk to remain profitable. Intermediation is at the core of our growth and profitability as we don't have an option to pursue further on other engagements due to their limited scope of expansion and availability. In addition, the banking system is not supported by both primary and secondary markets due to lack of well developed stock and bond markets. '(Interview BM7).

'What we need to be profitable is to mobilize local resources as much as possible. We know that there is a stiff competition to get forex resources abundantly. The high demand for credit also a pushing factors towards channeling our business in the intermediation front.'(Interview BM12).

The above explanation shows that the lack of well developed market (primary and secondary) has limited banks' choice related to risky activities. Despite the high risk attached to intermediation activity, the banks' drive has been to push hard to mobilize local resources from the market and lend it to the needy customers. The underdeveloped market doesn't allow them to diversify their business through offering additional services like investment banking and others. Furthermore, the high rivalry in the forex market has put the banks in rare option to diversify their business undertakings.

\section{Expense Preference Behavior/Quiet Life}

Even if the banks are operating in highly concentrated markets, ensuring efficiency through controlling scale of operations and improving their managerial efficiencies remain an important element of the banking business. Therefore, with the intent of exploring justifications for the aforesaid rational, a specific research question, i.e. what may be the reason towards a high expense control behavior in your bank?, was designed to get the banks' view on it. The interview data shows that the managers agree that managing expenses have been a focus of management. This is because banks have a limited option of revenue growth sources and believe that expense growth related to salary, general and administrative expenses has impact on profitability of banks. For example a bank manager BM11 noted that:

'Managing expense is one of the critical activities of management. Expense growth unless managed could consume our earning, which is collected from limited revenue channels...' (Interview BM11).

Banks even view that the growing expenses has impacted the management decision on long term growth ensuring activities such as pursuing further expansion, enhancing technology capacity, introducing new products, promotion etc.

'....We know that our growth endeavor should balance on activities that ensure short term profitability and long term institution build up. Nevertheless, our expense size sometimes coerces us to focus on short-term goals as we need to pay a good level of dividend to our shareholders.' (Interview BM7). 
The study also aimed to get explanation with regard to the positive relationship between market power and managerial efficiency. In view of this, a question has been extended for banks managers to indicate areas whereby the management witnesses a relaxed expense decision.

'We by regulation are required to set a dedicated budget for human capital development, which is 2\% of our total capital expenditure.'(Interview BM3).

'Our branch expansion strategy as well as employment decisions are sometimes involves the direction

from the government. Even if the expenses have implications on our profitability we do it as instructed as we are established to fulfill objectives beyond profitability.' (Interview BM7).

Overall, as observed from the explanation, banks generally have no preference to expenses. Therefore, banks cannot easily adjust their prices to compensate for the change in expenses, mainly related to operations. In addition, banks have limited scope of revenue sources which allow engaging in a relaxed expense management. Consequently, expense control is considered by the banks as an important driver to maintain profitable banking operation. Such attitude on expense even if allowed to meet the profitability motive, it remained a constraint to drive banks' interest towards long term growth ensuring activities. This obviously limits the competitive capacity of banks through establishing a differentiation theme as discussed in previous section. In some cases, like employee capacity development, however, banks by regulation are required to prefer expenses. In addition, state owned banks with development motives are required to prefer expenses to fulfill the needs of the society for banking service through opening large network of branches as well as creating employment opportunities to new graduates. Therefore, the study finds that regulation and influence of owners (like state) remains one of the determinants of bank conduct with regard to expense preferences.

\section{Cooperation Strategies}

One of the conducts of banks operating in high concentrated market is a cooperation strategy designed by banks to win the rivalry arising from big commercial banks. More specifically, small banks which standalone cannot cope up the competition move of the big banks that prefer to form an alliance with other banks in their group. The study finds that there has been an attempt from private banks to form an alliance with regard to avoiding competition in the form of prices. With the objectives of exploring further areas of alliances, we have set a question that reads, 'what are the cooperation areas of your bank with other banks?'. The study finds that there is an established alliance as framed by the regulator for banks to cooperate in information sharing, common use of ATM networks, automated payment system. Nevertheless, banks have no well designed cooperation strategies except on few cases related to information sharing on borrowers profile, bank performances, etc.

'We don't set a strategy to create alliance with other banks. We usually consider other banks as our competitors not our alliances...' (Interview BM9).

'We usually cooperate in sharing information related to borrowers. We share some resources like ATM and the payment system as it is prescribed by the NBE. '(Interview BM13).

Overall, banks including the small banks don't attempt to respond to the threat arising from the competition from big banks through establishing a strategic alliance framework. The alliance observed in the system is usually derived from the push from the NBE for shared use of resources and information sharing. This has limited the opportunity for banks to perform well in some fronts. For instance, small banks can extend large loans by involving in syndicated lending practices with big banks. Such practice, however, is not well developed because of the banks' views in considering other banks as competitors not a strategic alliance partners to boost their operation in some areas. Therefore, banks are pursuing a standalone competitive strategy which in the longterm challenges small banks' capacity to set down the rivalry arising from the big counterparts.

\section{Other Bank Conduct Determinants}

The qualitative study also investigated conducts of banks other than the one explored above considering the market structure with the aim of exploring additional determinant of banks behavior. Some banks managers pointed that employee retention which affects customer retention is one of the competitive strategies of their banks.

'Retention of key customer contact employees was very important for maintaining existing customers.

Successful staff retention strategies could provide opportunities to retain existing customers which otherwise switch to other banks subsequent to the resignation of the key staff.' (Interview BM12).

'We compete with banks not only by snatching customers but keeping our key staff. In such endeavor, we always set our compensation and benefit package at the top of the industry.' (Interview BM7).

A manager in interview also stated that their top management reputation is crucial in terms of helping them convince customers.

'Banks are in a game to attract reputable managers to run their business and the one with the best management group would win the game.'(Interview BM14).

Others also suggest that the quality of relationship with shareholders, which determines the existence of board 
and top management stability, as an important element of their bank growth.

'I think the quality of the relationships with our shareholders is a key to create board and management stability as the shareholders are powerful to enforce continuity or removal of bank management and board.' (Interview BM2).

In sum, the qualitative study finds some important variables impacting conduct and performances of banks. These include employee retention, top management reputation and relationship with shareholders, which impact customer retention, new customer acquisition and stability of board and management, respectively.

\section{Summary and Conclusions}

Summary

With regard to conduct, the behavior of banks:

- On the price aspect, one of the important findings of the study is that price collusion has not been the norm observed in the Ethiopian banking system. Even if there has been an effort from the private banks system to engage in price collusions, its effect has been not significant but has helped banks to enjoy stable earnings from intermediation business with a liberty to alter their lending prices in a way to keep their spread constant. Therefore, price remains not a worry to the banks and is not considered as an essential parameter to change performances. In addition, price related measures are discouraged through regulation, different motives of state owned and private banks, substantial size difference, risk taking behavior and market protections.

- $\quad$ Bank product offering in the banking system remains homogenous as a result of lack of patents for bank products and the tendency to get easily copied. Although managers and regulatory staff in general recognized that bank product offerings are homogenous, they consider them as a key source of their competitive advantage

- Service difference has been an important reaction taken by the banks to win market share and build their competitive advantage. This however is driven by both:

$\circ$ Internal and intentional motive of the management to attract customers

- A regulatory direction that encourage banks to compete and differentiate themselves from the move of the market.

- Banks have been promoting themselves through a mix of approaches and consisting of personal selling, customer visit, TV and radio advert, publications (newspapers and magazines), social media, lottery offerings etc. Nevertheless, aggressive promotion attempt through TV and radio presence targeting the mass market is affected by the high investment requirements. This enforced banks to divert there promotion approach to other cost effective media like social medias.

- The banking system in Ethiopia mostly follows a mass market approach addressing the need of both retail and corporate clients with undifferentiated product and marketing approaches. In addition, regulatory measures also discourages differentiation related to market demanding for a homogeneous market reach and ensuring a growth approach through opening large branch networks mainly serving of the retail businesses.

- Despite its high investment requirement, ensuring proximity thorough branch networks remained the strategy of the banks. This is also further exacerbated by the regulator demand.

- Innovation appears to be one of the behaviors determining bank conduct in the Ethiopian banking system. Nevertheless, its level of impact has been challenged to impact the industry performances due to several factors including costs, lack of capacity, low awareness level, easy adoption rate, lack of well developed infrastructure and regulatory barriers.

- Merger and acquisition is not considered as one way of ensuring growth in the banking system. Except on few cases, banks strategy entirely relies on organic growth. This is because of the convenient scenario in the industry to ensure natural growth as well as variation in the market segmentation strategy of banks.

- Lack of well developed market (primary and secondary) has limited banks' choice related to risky activities. Despite the high risk attached to intermediation activity, the banks drive has been to push hard to mobilize local resources from the market and lend it to the needy customers.

- As shown in the study, the test for the quiet life hypothesis has rejected the existence of a quiet life scenario in the Ethiopian banking industry. Even if the banks are operating in highly concentrated markets, ensuring efficiency through controlling scale of operations and improving their managerial efficiencies remains an important element of the banking business.

- Banks including the small banks don't attempt to respond the threat arising from the competition from big banks through establishing a strategic alliance framework. The alliance observed in the system is usually is derived from the push from the NBE for shared used of resources and information sharing. 
- The qualitative study finds some important variables impacting conduct and performance of banks. These include employee retention, top management reputation and relationship with shareholders which impacts customer retention, new customer acquisition and stability of Board and management, respectively.

\section{Conclusions}

The study uses the views from both bank mangers and regulators to investigate the behavior of banks operating in a concentrated market. As identified in the literature, such variables as bank conduct, has been a neglected topic in the traditional SCP hypothesis. This is due to the claim that bank conduct is a derivative of the industry structure on the one hand and the difficult to quantitatively test the behavior of banks in the system as the proxy variables are not quantitative by nature or else data is not available as they are not represented in the financial records of banks. The study however finds that bank conduct is not necessarily a derivate of the industry structure. There are various factors beyond concentration that are mainly from internal, external and regulation that are shaping the conduct of banks in the industry. Such findings from the qualitative approach witnessed a different behavior of banks than the one suggested in the SCP hypotheses. For instance, given high market concentration, banks in Ethiopia are behaving differently in price competition which remains a less essential parameter to change performances. Service difference has been an important reaction taken by the banks. Banks have been promoting themselves through a mix of approaches and attempted to increase their market share via increasing branch networks. In addition, besides market structure, regulation has been the most important variable affecting banks performance via encouraging homogenous service offerings, similar bank growth strategies and controlling their asset quality positions. Unlike what is claimed in the SCP hypothesis, the qualitative study shows that organic growth, not merger and acquisition, is considered as a dominant strategy that ensure growth in the banking system. Bank risk taking behavior also appears in contrast to the hypotheses as banks behavior towards risk is guided by the development status in the financial market as well as the competition level in alternative markets like foreign banking. The quiet life test result is also unlike the one suggested by the SCP hypotheses as banks are found to be conscious in their expense management decision. This has been a different result had a structure based derivative has been followed in the study. The qualitative study also explored additional variables determining bank conduct such as employee retention, top management reputation and quality of relationship with shareholders.

\section{References}

Alvesson, M. and Sköldberg, K. (2009). Reflexive Methodology: new vistas for qualitative research. London: Sage.

Bain, J. (1951).The Relation of profit Rate to Industry Concentration, American Manufacturing, 1936-1940, Quarterly Journal of Economics, vol.65 (3), pp.293-324.

Bain, J. (1956). Barriers to New Competition,Harvard University Press, Cambridge, MA

Bain, J. (1968). Industrial Organization 2nd edition, John Wiley and Sons Inc., New York.

Berger, A., and Hannan, T. (1989). The Price-Concentration Relationship In Banking, Review of Economics and Statistics, 71 ,pp.291-299.

Bezabeh A. and Desta A. (2014). Banking Sector Reform in Ethiopia, International Journal of Business and Commerce, Vol. 3,.8, pp. 25-38.

Bikker, J. and Haaf, K.(2002a). Measures of Competition and Concentration in the Banking Industry : a Review of the Literature. Economic and Financial Modelling, pp.1-46.

Bryman, A. (2004). Social Research Methods (2nd edition). Oxford University Press.

Bryman, A. (2004). Social Research Methods (2nd edition). Oxford University Press.

Craswell. J. (2003). Research design: Qualitative, quantitative, and mixed methods approaches. 2nd ed. Thousand Oaks, CA: Sage.

Craswell. J. (2003). Research design: Qualitative, quantitative, and mixed methods approaches. 2nd ed. Thousand Oaks, CA: Sage.

Denzin, N. and Lincoln, Y. (2005). The SAGE handbook of qualitative research (3rd ed.),Thousand Oaks, CA, Sage.

Ferguson, P., and Ferguson, G.(1994). Industrial Economics: Issues and Perspectives. 2nd edition. The Macmillan Press LTD.

Firmin, M. W. (2008). Replication. In L.M. Given (Ed.), The Sage encyclopedia of qualitative research methods (Vol.2, pp. 754-755). Thousand Oaks, CA:Sage.

Gill, J., Johnson, P., and Clark, M. (2010). Research methods for managers (4th ed.). London: Sage.

Grey, D.(2014). Doing Research in Real World, 3rd ed. Sage Publications

Grigorova, N., Muller, J., Huschelrath, K. (2008), The Plausibility of the SCP Paradigm for Strategic Industry Analysis - Evidence from the Bulgarian Mobile Telecommunications Industry. Paper presented at the 17th 
Biennial Conference. Doi: http://www.canavents.com/its2008/abstracts/276.pdf

Harvey, C. (1996). Banking reform in Ethiopia, Working Paper 37, Brighton: Institute of Development Studies.

Hicks, J.(1935).The Theory of Monopoly. Econometrica, 3, 1-20

Johnson, R. , Onwuegbuzie, A., and Turner, L. A. (2007). Toward a definition of mixed methods research. Journal of Mixed Methods Research, 1(2), pp.112-133.

LeCompte, M. \& Goetz, J. (1982). Problems of reliability and validity in ethnographic research. Review of Educational Research, 52(1), 31-60.

Lelissa, T. (2007). The Impact of Financial Liberalization on the Ownership, Market Structure and Performance of the Ethiopian Banking Industry (Masters Thesis, Addis Ababa University).

Lera D. and Rao .P. (2016). Market Structure, Efficiency, and Performance of the Ethiopian Banking Sector ; India Journal of Research, Volume : 5 , Issue : 1 ,January 2016

Lincoln, Y. and Guba, E.(1985). Naturalistic inquiry. Beverly Hills, CA: Sage.

Lipczynski, J., Wilson, J., and Goddard, J. (2013). Industrial Organization, Competition, Strategy, Policy. FT Prentice Hall, London, second edition.

McMillan, J., and Schumacher, S. (2006). Research in education, Evidence-Based Inquiry, New York, Pearson Education, Inc.

Mohamed, Z., Shamsudin, M. , Latif, A., and Mu'azu, A. (2013). Measuring competition along the supply chain of the Malaysian poultry industry. International Conference on Social Science Research, 4-5 June 2013, Penang, Malaysia.

Moore,R.(1973). Concentration, Technology, and Market Power in Banking, Is Distance Dead? Federal Reserve Bank of Dallas Financial Industry Studies, December 1998, pp. 1-10.

Neuberger, D. (1997). Structure, Conduct and Performance in Banking Markets. Thuenen-Series of Applied Economic Theory 12. University of Rostock, Institute of Economics, Germany

Perry, P. (1992). Do banks gain or lose from inflation?, Journal of Retail Banking, Vol. 14 No. 2, pp. 25-30.

Purcell,D. (1973).An Approach to Research on Vertical Integration: The Beef System in Oklahoma, American Journal of Agriculture Vol. 55, No. 1.

Rubin, J.and Rubin, S. (2005). Qualitative interviewing: The art of hearing data (2nd ed.). Thousand Oaks, CA: Sage.

Rubin, J.and Rubin, S. (2005). Qualitative interviewing: The art of hearing data (2nd ed.). Thousand Oaks, CA: Sage.

Sahoo, D. and Mishra, P. (2012). Structure, conduct and performance of Indian Banking Sector. Review of Economic Perspectives, 12(4), 235-264.

Sahoo, D. and Mishra, P. (2012). Structure, conduct and performance of Indian Banking Sector. Review of Economic Perspectives, 12(4), 235-264.

Saumure, K., \& Given, L. M. (2008). Data saturation. In L. M. Given (Ed.), The Sage encyclopedia of qualitative methods (Vol. 1, pp. 195-196).

Seale, C. (1999). Quality in qualitative research. Qualitative Inquiry, 5(4), pp.465-78.

Shafer, S. (2004). Patterns of competition in banking. Journal of Economics and Business, Vol. 56, $287-213$.

Shepherd, W. , and Wilcox, C. (1979). Public policies toward business. 6th edition. Richard D. Irwin, Inc.

Silverman, D. (2000). Doing Qualitative Research, A Practical Handbook. London, Sage.

Stenbacka, C. (2001). Qualitative research requires quality concepts of its own. Management Decision, 39(7), pp.551-555.

Tashakkori, A., and Teddlie, C. (1998). Mixed methodology, Combining qualitative and quantitative approaches. Thousand Oaks, CA: Sage.

Yin, R. (2003). Case study research: Design and methods (3rd ed.). Thousand Oaks, CA: Sage.Zineldin,H. (2011). Strategic positioning and quality determinants in banking service", The TQM Journal, Vol. 23 Iss 4 pp. $446-457$.

Zineldin, Mosad (2011), Bank strategic positioning and some determinants of bank selection. International Journal of Bank Marketing, Volume 14/6, pp. 12-22. 